\title{
Touchless automatic as innovation on modern waste place developing anti-decay catted temperature cold with the application of anti-bacterial spray cooling system
}

\author{
Sugiarto Anton ${ }^{1}$, Al Falah Hayat ${ }^{2}$, Ekawati Lina $^{3}$ and Isworo Slamet 3 , * \\ ${ }^{1}$ Medical Records and Health Information Program, Faculty of Health, University Dian Nuswantoro Semarang, \\ Indonesia. \\ ${ }^{2}$ Industrial Engineering Program. Faculty of Engineering. University Dian Nuswantoro Semarang, Indonesia. \\ ${ }^{3}$ Environmental Health Program, Faculty of Health, University Dian Nuswantoro Semarang, Indonesia.
}

Publication history: Received on 23 July 2018; revised on 14 August 2018; accepted on 07 September 2018

Article DOI: https://doi.org/10.30574/gscbps.2018.5.1.0069

\begin{abstract}
Garbage becomes controversy in a quite complicated world because of the great loss to the environment and health caused by garbage. Therefore, the need for the development of appropriate technology that underlies the preventive attitude due to the waste. The method used is a robot system that works to automatically control garbage. Methods of implementation include 1. Case Analysis: tool-making begins with analysis on some cases that occur in the community. 2. References: look for references that match the created device. 3. Designing the design: the operating system uses four sensors, anti-bacterial spray, garbage freezing, and hand sanitizer. 4. Creating a prototype after the design is continued with the manufacture of prototype which includes electrical design and work system with anti-bacterial spray. 5. Prototype testing and completion of tools: the refinement of the tool is performed after testing to correct any deficiencies in the device. This research is a creative research work in dealing with unpleasant odor due to decay in household trash as innovation on modern waste place developing anti-decay catted temperature cold with the application of anti-bacterial spray cooling system with temperature control $0{ }^{\circ} \mathrm{C}-15^{\circ} \mathrm{C}$. No decay and no bad smell.
\end{abstract}

Keywords: Garbage domestic; Touchless automatic; Bacteria decay; Four S-Bin; Automatic sensor; Controlled temperature

\section{Introduction}

Waste is something that is not used, not used, or something that is removed from human activities derive from natural weathering activities. Waste is one of the big problems of the problems that exist in Indonesia [1]. Even the busyness of human activity is the factor in the formation of waste with the greatest number due to the lack of awareness. According to data from Indonesian National Standards 19-3964-1995, the municipal solid waste every day reaches 2-2.5 Liter / person / day not to mention garbage dumping in the trash cans in the room. In urban areas, especially in public facilities or rooms, such as hospitals and hospitals, they are not aware of the dangers of the waste they produce, thus allowing unknown disease problems to occur. The danger of the disease is caused by the accumulation of waste that is not separated between organic wastes with inorganic waste of the factors between waste generations in offices or in the room there are types of waste piles in Indonesia [2].

The problem of urban waste, especially in hotels, apartment becomes very important because of the busyness of the urban community so that often the garbage disposal is not routinely disposed of, this causes an uncomfortable condition and the potential for disease. Therefore, it is a necessary innovation in overcoming the garbage which is a place of

\footnotetext{
${ }^{*}$ Corresponding author

E-mail address: slamet.isworo@dsn.dinus.ac.id
}

Copyright (C) 2018 Author(s) retain the copyright of this article. This article is published under the terms of the Creative Commons Attribution Liscense 4.0. 
temporary waste, so it takes a waste bin that can prevent decay, as an alternative waste problem that cannot be discarded and a waste bin that can prevent decay. Touchless Automatic As Innovation On Modern Waste Place Developing Anti-Decay Catted Temperature Cold Temperature With Application Of Antibacterial Spray Cooling System is an innovation of the intelligent dumpster as a temporary place before it is discharged to a final disposal site that can prevent decay so that odor problems and potential disease for while it can be prevented, before the waste is disposed of in the final dump [3].

Touchless Automatic As Innovation On Modern Waste Place Developing Anti-Decay Catted Temperature Cold With Application of anti-bacterial spray cooling system aims as an appropriate technology to prevent foul odors spreading in air, especially indoors due to waste that is not thrown away, handling while disposal, garbage in the room and health, preventive efforts due to impacts caused by waste and the use of anti-septic to prevent the development of bacteria by hand washing activity $[4,5]$.

\section{Material and methods}

\subsection{Materials}

Elektronic tool kit 40 Pcs (Bosch, Germany), Soldering iron kit electronics welding irons tool 60 W adjustable temperature (Perkside-Germany), Cutting pliers 152.5 mm, N9150-8850, 323-8920 (Hozan-China) , combination pliers (Hozan-China), Screwdriver souder (Black+Decker, USA), Screwdriver plus minus (Bosch, Germany), Grendra tools (Kolver, USA), Wood material (Local-Indonesia), Arduino Uno Rev (Velleman, English), Screw nut cable and universal serial bus (USB) Cable (Chang Enn, Chine), Printer proxymity sensor (Misumi, Japan), Rt809f Usb Programmer Motherboard LCD reader with sop simple socket vga Cable, Japan) , Jack comp.3p (Misumi, Japan), Adapter 12 V Sony Ac-122 AC (Sony Japan) , Iron ram (Sony Ac-122 AC) , Switch (Sony, Japan), Insuloc 3 mm (Local, Indonesia), Insuloc 4mm (Local Indonesia), Direct current stopper cable (BMA Tech-Hongkong), Small socket (BMA Tech-Hongkong), Rainbow cable lop (BMA Tech-Hongkong), Black housing cable (BMA Tech-Hongkong), federa Cable 2 x prime (Shanghai Tiancheng Smart Systems Co, Ltd. Shanghai, China), Direct current iron socket (Shanghai Tiancheng Smart Systems Co., Ltd. Shanghai, China), compressor (Shanghai, China), condenser (local, Indonesia), Hose (Radcoflex Australia), thermostat (Misumi, Japan), Filter contents (Misumi, Japan), Freon R 134 (Dupont, French), gypsume bolt nut (Local, Indonesia), Evap 23x43 (Indonesia), Armaflek 1/4 (Indonesia), Pipe 1/4 (Indonesia), Bevel gear (Misumi, Japan),. Gas welding tube (Lokal, Indonesia), Federal cable (Asus, Taiwan), Tenol (Local, Indonesia), Lem fox (Local, Indonesia), Sandpaper (Local, Indonesia), Triplex $4 \mathrm{~mm}$ (Local, Indonesia), 1 ampere transformer. 35 Volt (Local, Indonesia), Skun power supply IC (Lokal Indonesia), Socket (Local, Indonesia), Dioada 16 V Potensio (Indonesia), PCB viber (Indonesia), Stepdon 3 Ampere (Nasional, Indonesia), Antiseptic Gel (OneMed Indonesia), BIO-Anti odor (Indonesia), Laker Afduner Softaman alcohol (Braun, German Society).

\subsection{Methodology}

The steps of making this prototype system are as follows: [6]

- Case Analysis: The preparation of the tool begins with analysis on some cases that occur in the community how to monitor the situation of TPS located around the house. Analyzing the incidence of how many cases of waste dumping caused by a worker's work.

- Search for References: Search for references that match the device being created. Search the appropriate journals and articles to have a solid foundation in the making.

- Designing Design: The operating system uses the concept of compressor refrigeration and 4 (four) sensors that support the performance of the main tool to inhibit the waste decay in order to avoid significant bacterial and viral reproduction. For that sensor can affect the workings of Four S-Bin.

- Creating Prototype: After the design is continued with the manufacture of prototype which includes the design of electrical and body of the trash. Mechanics and electronics as a performance process in the Four S-Bin trash.

- Test Prototype: Testing the prototype has been tested, whether the cooling system is able to work temperature $-8{ }^{\circ} \mathrm{C}$ to $0{ }^{\circ} \mathrm{C}$, to inhibit the proliferation of bacteria and prevent bad smell. Testing is also done by inserting the program into the microcontroller as pebgujian anti-bacterial gel automatic door sensor and testing antibacterial spray timer. 
- Tool Enhancement: Completion of the tool is done after testing to correct any deficiencies found on the device. Adding components or replacing components better than a ready-made device. Figure 1 below shows the research flow diagram, as follows:

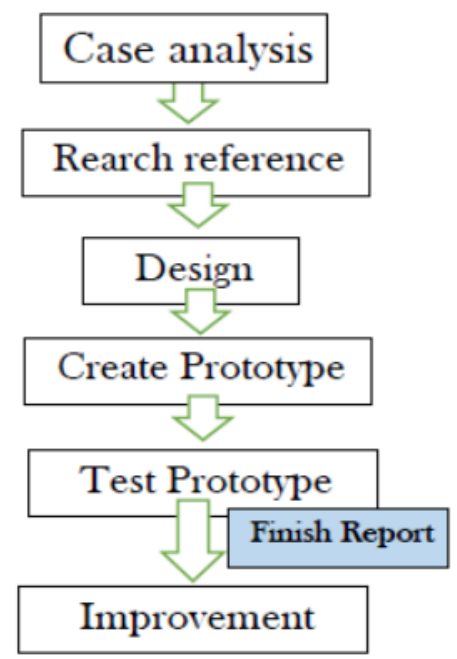

Figure 1 Flowchart making tool Touchless automatic

\section{Results and discussion}

Touchless automatic is a form of development of electro, biology and biomedical sciences in dealing with the problem of trash that is stored temporarily. Automation of dumps is achieved through the use of power supply, Controller (Arduino Uno), human / waste recognition system, PIR sensor, servo motor and antiseptic sensor. The figure 2, shows the flow chart of the automatic door and hand sanitizer program. Based on the method [7] that is implemented, the flowchart of the Four S-Bin-Touchless automatic prototype is created (figure 3).
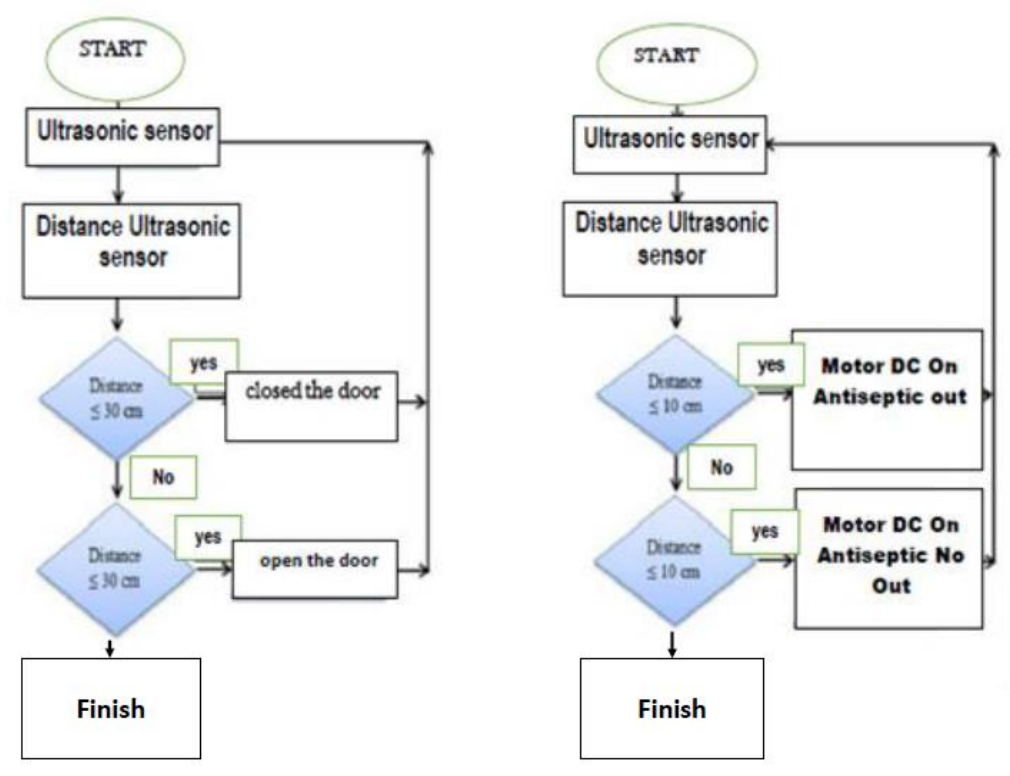

Figure 2 Flowchart program automatic doors and hand sanitizer 


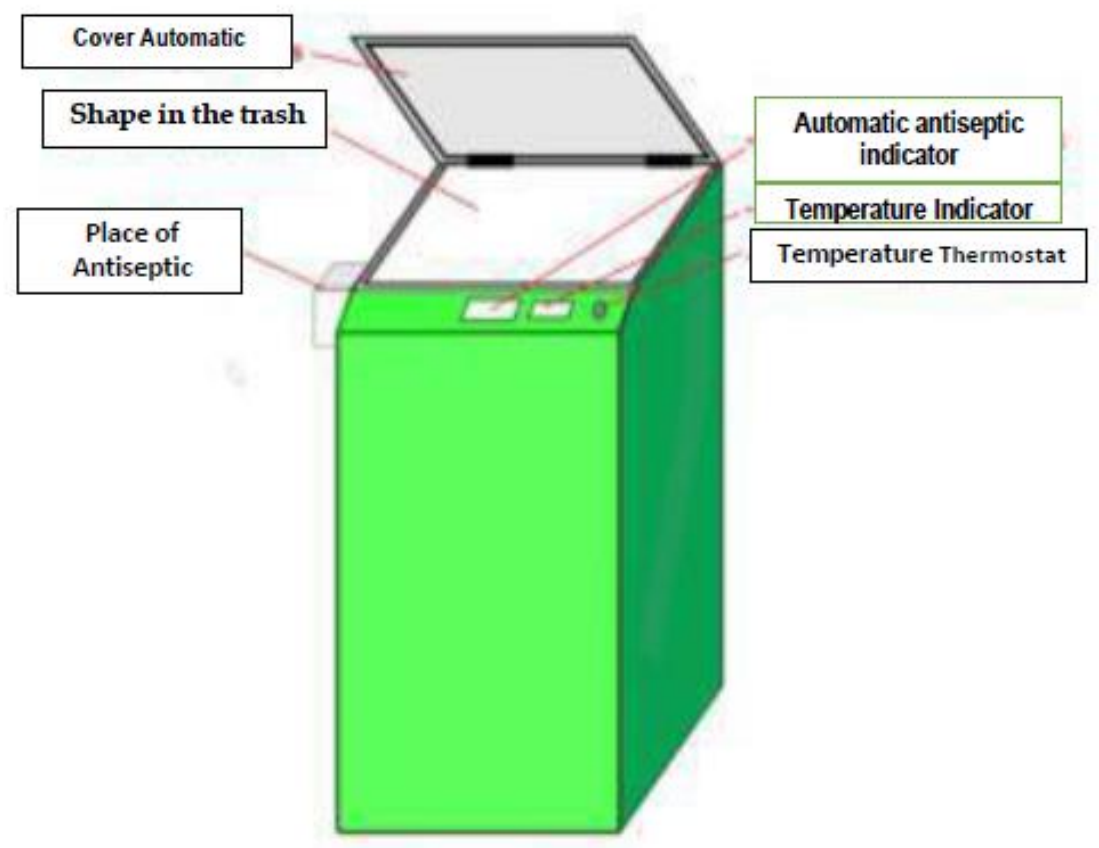

Figure 3 Four S-Bin Touchless automatic prototype plan

Four S-Bin Touchless automatic is a technology developer of trash in the modern era by utilizing automatic temperature sensor, antiseptic and human sensor. The technology also utilizes a cooling technology sensor so that it can regulate the temperature in the trash, the temperature can be set on certain conditions so that the garbage spoil bacteria cannot develop and can inhibit decay [8]. The sensor is programmed are performed on the dump as controls on automatic doors and automatic anti-septic gel. Both use the same concept that is with the concept if ultrasonic sensor SRF04 detects objects with distance $\leq 30 \mathrm{~cm}$, then servo work opens the door. The next door will be closed or the servo will return if the ultrasonic sensor of SRF04 does not detect objects or distance $\geq 30 \mathrm{~cm}$. Likewise with automatic antiseptic, if ultrasonic sensors detect objects with a distance of $\leq 10 \mathrm{~cm}$, then the DC motor work out anti-septic for a few seconds. Conversely, if the object has not detected the direction of distance $\geq 10 \mathrm{~cm}$, then the motor does not work because input does not get a signal. The test is done on the tool in three stages, namely, the first stage is testing the automatic cover section by closing the object in the form of garbage in the face cover with a few centimeters when open and closed again with automatic, then the first stage is declared successful. The second stage, namely the cooling system by inserting organic waste into the Four S-Bin and then wait some two or three days if the decay slows down, then the second stage is declared successful. In the third stage of testing, an automatic fragrance test is performed by setting a timer of 8 (eight) hours per day, in which the garbage bin that runs within 8 (eight) hours per day will automatically emit anti-bacterial sprays in the bin, this will work thirdly no abuser and/or garbage detected. The last stage is testing on automatic antiseptic, at this stage, the garbage disposal will close hands to antiseptic so antiseptic will issue antiseptic gel because the sensor receives the signal through a hand. The division of this testing stage is done to further facilitate the possible troubleshooting $[9,10]$.

Stages of the process of running the program are the user who became the media on the sensor to open and close the garbage cans automatically, with a cooling system cycle which became an intermediary of solid waste and bacteria. In addition, infrared sensors using the Arduino program and DC motors also become excess in the inhibition of bacteria undergoing a comprehensive breeding System performance is divided into 4 four) parts: i. Cooling system(figure 4), ii. The system works the door (figure 5), iii. The system works hand sanitizer (figure 6) and iv. Spray anti-septic system work (figure 7) [11]. 


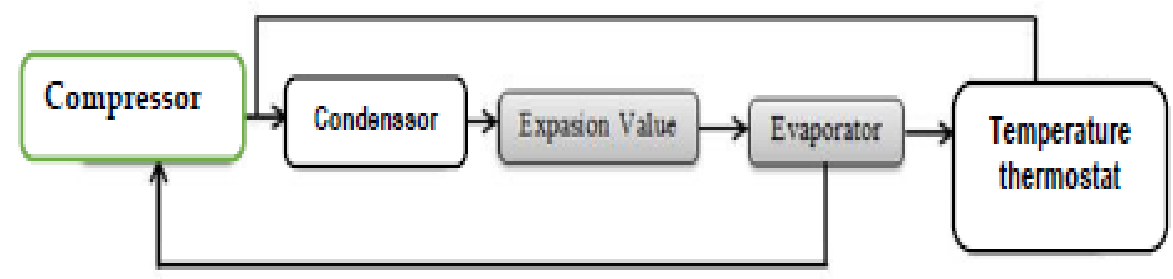

Figure 4 Cooling work system

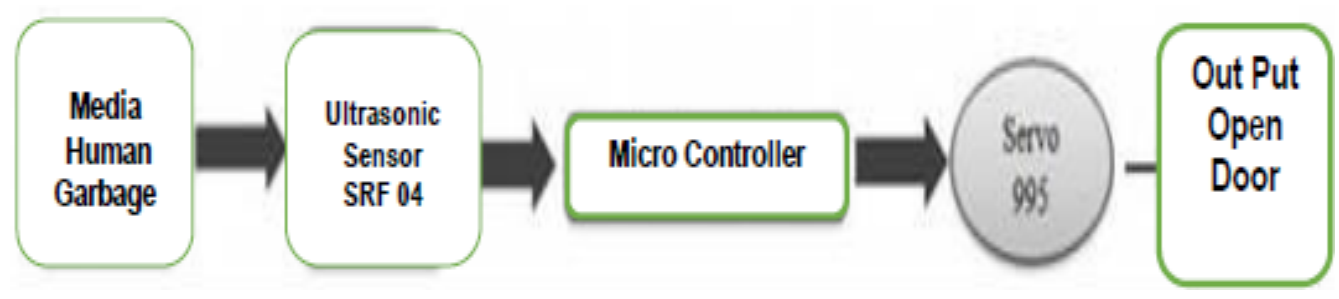

Figure 5 Automatic door working system

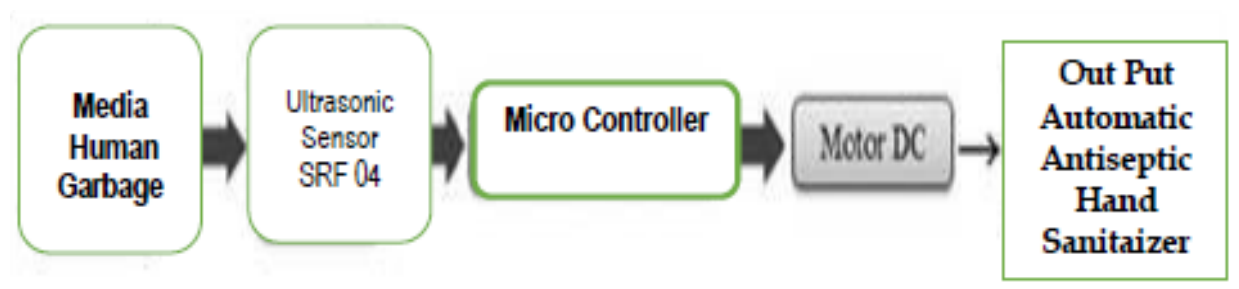

Figure 6 Hand sanitizer working system

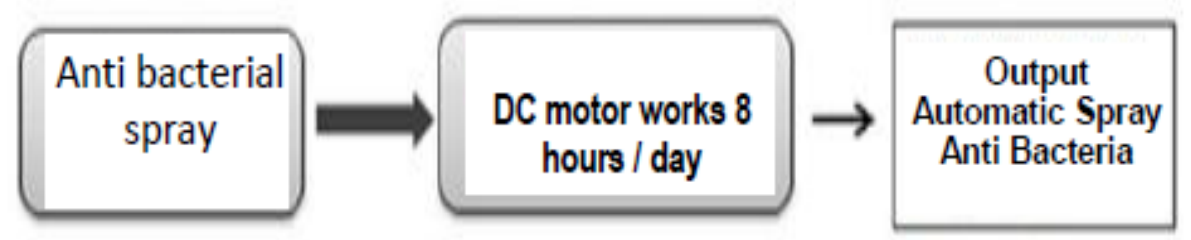

Figure 7 Spray anti-septic system

Components of Touchless automatic which examined itself consists of the compressor, condenser, expansion value, evaporator, the microcontroller (Arduino Uno), servo motor 995, ultrasonic sensor SRF04, DC motor and step down the power supply. A compressor is a power unit in the cooling machine system. The compressor functions to pump the refrigerant throughout the refrigerator. The compressor will pump refrigerant gas under high pressure and heat at the high-pressure side of the system and suck low-pressure gas on the intake side (low-pressure side). The condenser has a function to remove hot air from Freon which is used to come from AC compressor. So Freon which was originally gasshaped changed into liquid after an assisted cooling fan or cooling fan, without a condenser, the initial Freon gas will not turn into liquid [12].

Arduino Uno is an Atmega 328 microcontroller circuit board. The integrated circuit has 14 digital inputs/outputs (6 outputs for PWM), 6 analog inputs, $16 \mathrm{MHz}$ ceramic crystal resonators, USB connections, adapter sockets, ICSP header pins and buttons reset. This is what is needed to support the microcontroller easily connected with AC adapter power supply cable to DC or also battery [13]. While the PIU is an aluminum cork material capable of withstanding the cold at the pressure of the cooling system, while the cooling circulation starts to operate will discharge water as the output of evaporation disposal. 

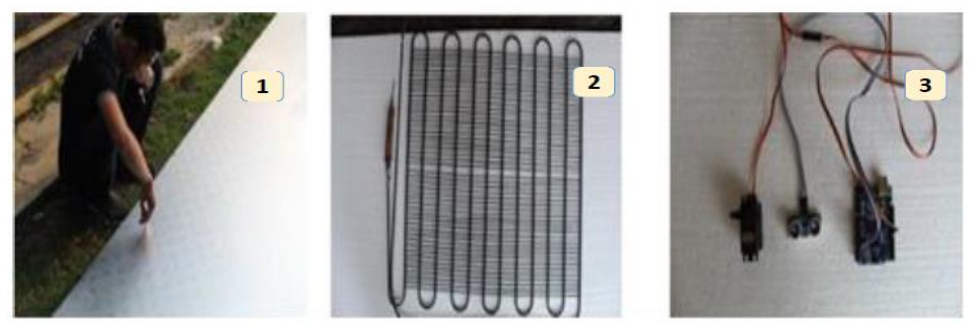

Figure 8 Material of the trash box (1), Uno Rev condenser (2) and door scavenging (3)
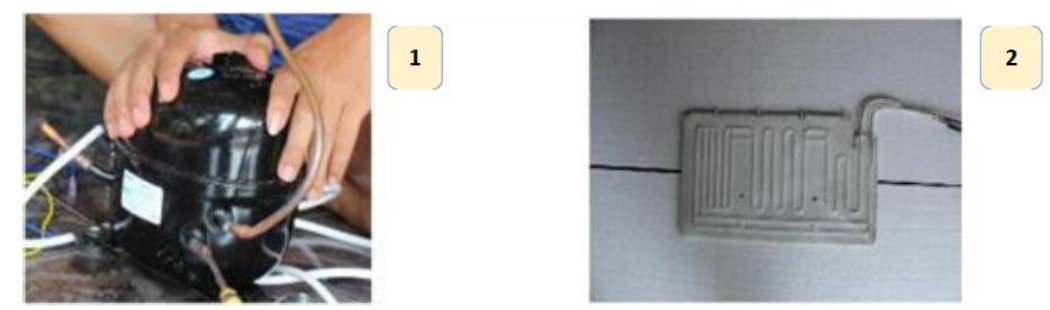

Figure 9 Compressor (1) and Evaporator (2)

The process of making a decomposition in the waste decomposition is also called Four S-Bin first with a joint analysis, following the prototype design drawings [Figure 10].
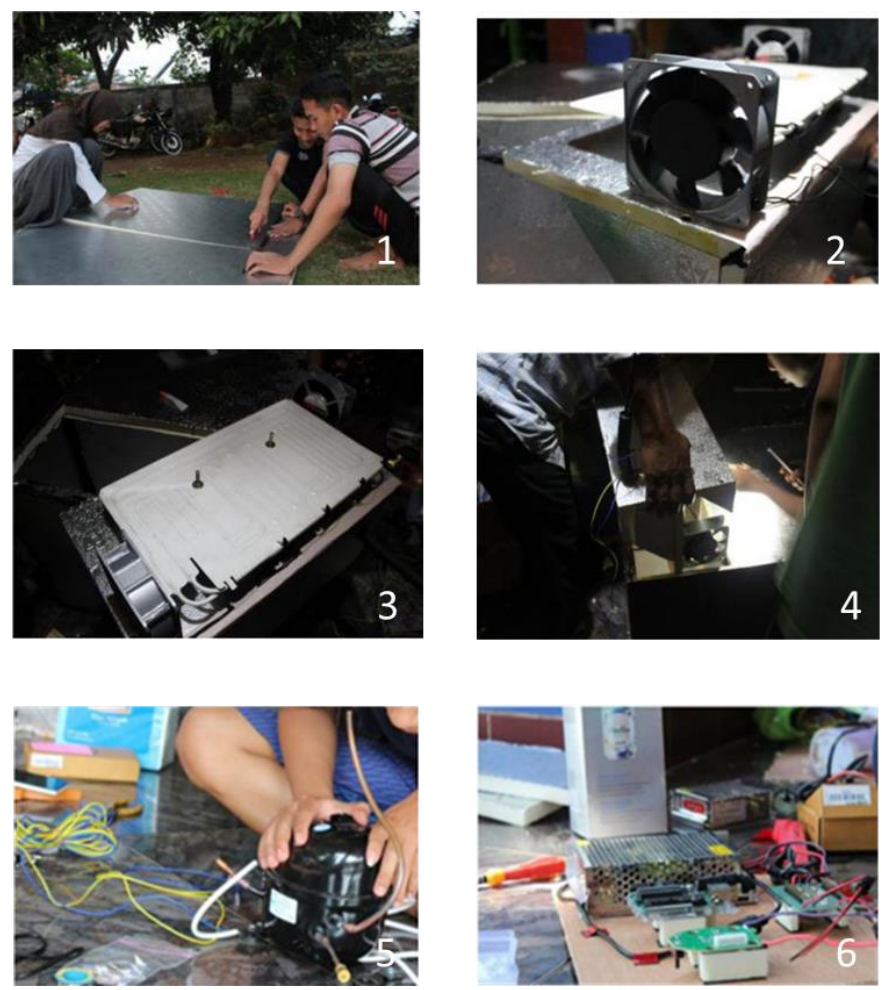

Figure 10 Cutting PIU (1), fan installation (2), installing evaporator and tool into prototype $(3,4)$ and installation of electrical devices on the compressor $(5,6)$

In the making of the simulation, there are three different rooms, each room has a different working system. In the front frame, there are various electrical sensors, including the ultrasonic sensor that serves as the output hand sanitizer while in spray anti bacteria waste using timer program, the proximity sensor is used to automatically open the door and indoor temperature using temperature timer. The second chamber is a pressure pump or compressor, an evaporator to vaporize the air pressure from the compressor to cold temperatures, fan to neutralize cold temperatures to avoid 
freezing, and a condenser that serves as a heat-engine filter from the compressor work. And the third space is a temporary garbage shelter so as not to experience the breeding of extreme bacteria in the waste using the timer program, the proximity sensor is used to automatically open the garbage door and indoor temperature using temperature timer. The second chamber is a pressure pump or compressor, an evaporator to vaporize the air pressure from the compressor to cold temperatures, fan to neutralize cold temperatures to avoid freezing, and a condenser that serves as a heat-engine filter from the compressor work. And the third space is a temporary garbage shelter so as not to experience the breeding of extreme bacteria in the waste [14].

Touchless automatic using the SRF04 ultrasonic sensor system so that the accuracy of the automatic distance is more controllable. The SFR04 sensor is an ultrasonic sensor that can measure the distance of $3 \mathrm{~cm}$ to 3 meters and is very easy to connect to the microcontroller using Input pin and Output pin. The SRF-04 sensor works by transmitting a momentary ultrasonic signal and generating an output pulse corresponding to the instantaneous reflection time of the ultrasonic signal back to the sensor. By measuring the width of the reflected pulse, the target distance in front of the sensor can be known. Therefore, this study is better and different from other studies [15].

\section{Conclusion}

Automatic trash can system, with touch technology that develops cold anti-cold-decay temperature with anti-bacterial spray cooling system application has been successfully carried out, the automatic sensor runs well, so the prototype has been formed. Automatic four-bin Touchless in prototype form which is very possible developed at the manufacturer's scale.

\section{Compliance with ethical standards}

\section{Acknowledgments}

The author is very grateful to the Chancellor and the vice chancellor - Dian Nuswantoro University who has provided facilities and funding for this research.

\section{Disclosure of conflict of interest}

All authors involved in this study stated that they did not have a conflict of interest regarding the research.

\section{References}

[1] Chaerul M, Tanaka M, Shekdar AV. (2007). Municipal solid waste management in Indonesia: status and the strategic actions. Journal of the Faculty of Environmental Science and Technology, Okayama University, 12(1), 41-49.

[2] National Standardization Agency. (1995). SNI. 19-3964-1995. Methods of measuring and measuring sample dump and urban waste composition, Jakarta.

[3] Hui C, Chun-Hui B and Qi-Chen M. (2016). Analysis of waste heat recovery technology of hot forging cooling system. Advances in Engineering Research, 115, 503-512.

[4] Alkhedhair AMS. (2015). Modelling and experimental study of spray cooling systems for inlet air pre-cooling in natural draft dry cooling towers. Thesis. School of Mechanical and Mining Engineering, University of Queensland.

[5] Sharma N, Singha N and Dutta T. (2015). Smart bin implementation for smart cities. International Journal of Scientific \& Engineering Research, 6(9), 787-791.

[6] Samann FE. (2017). The design and implementation of smart trash bin. Academic Journal of Nawroz University, 6(3), 141-148.

[7] Michael E, Otaru CO, Liman AD, Bomoi MI, Awotoye B. Design and Development of a Smart Waste Bin. International Journal of Scientific and Technology Research, 6(10), 101-105.

[8] Yang JC, Lai CL, Sheu HT and Chen JJ. (2013). An intelligent automated door control system based on a smart camera. Sensors, 13(5), 5923-5936.

[9] Hannan MA, Arebey M, Begum RA and Basri H. (2012). An automated solid waste bin level detection system using a gray level aura matrix. Waste management, 32(12), 2229-2238. 
[10] Satyamanikanta SD and Narayanan M. (2017). Smart garbage monitoring system using sensors with RFID over internet of things. Journal of Advanced Research in Dynamical and Control Systems, 9(6), 133-140.

[11] Naveen B, Kavya G, Kruthika S, Ranjitha K and Sahana CN. (2018). Automated waste segregator using arduino. International Journal of Advance Engineering and Research Development, 5(5), 255-259.

[12] Kabra N, Tirthkar P, Umak P and Deokar P. (2018). Automatic Waste Segregation Using Embedded System. International Journal of Innovations in Engineering Research and Technology, Conference Proceedings of TECHNO-2K17 (Technical Symposium), 1-13.

[13] Kumar RH, Roopa AU and Sathiya DP. (2015). Arduino ATMEGA-328 microcontroller. International Journal of Innovative Research in Electrical, Electronics, Instrumentation and Control Engineering, 3(4), 27-29.

[14] Alhawari AR, Alshehri AF, Alwadi MA, Blih FA, Almawgani AH and Alwadie AS. (2006). Design and development of electronic cooling and heating pad for hot and cold therapy. ARPN Journal of Engineering and Applied Sciences, 12(24), 7282-7289.

[15] Jo Y and Jung I. (2014). Analysis of vehicle detection with WSN-based ultrasonic sensors. Sensors, 14(8), 1405014069.

\section{How to cite this article}

Sugiarto A, Al Falah H, Ekawati L and Isworo S. (2018). Touchless automatic as innovation on modern waste place developing anti-decay catted temperature cold with application of anti-bacterial spray cooling system. GSC Biological and Pharmaceutical Sciences, 5(1), 09-16. 